
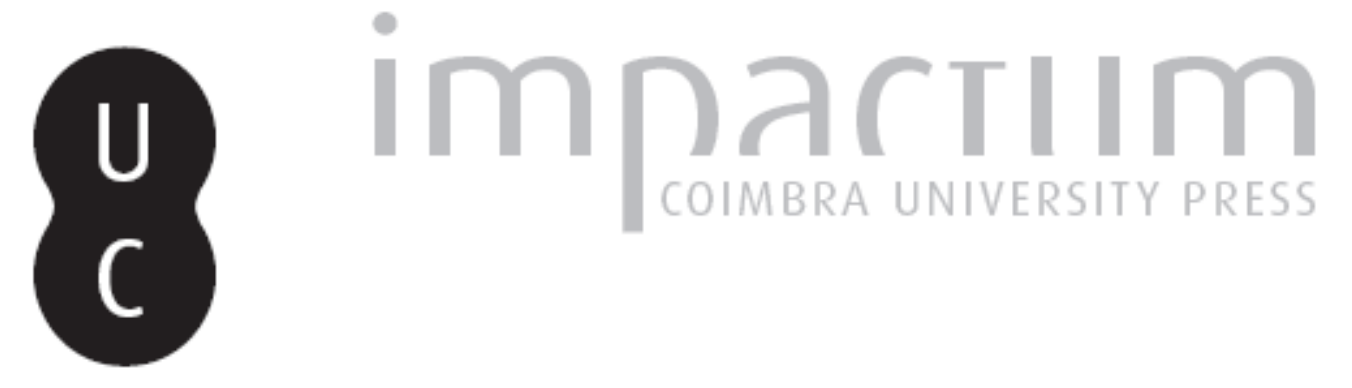

\title{
A desconsideração do nexo causal na responsabilidade civil ambiental
}

Autor(es): $\quad$ Souza, Neylene Fonseca

Publicado por: CEDOUA

URL persistente:

URI:http://hdl.handle.net/10316.2/40027

DOI:

DOI:https://doi.org/10.14195/2182-2387_25_6

Accessed : $\quad$ 26-Apr-2023 08:09:49

A navegação consulta e descarregamento dos títulos inseridos nas Bibliotecas Digitais UC Digitalis, UC Pombalina e UC Impactum, pressupõem a aceitação plena e sem reservas dos Termos e Condições de Uso destas Bibliotecas Digitais, disponíveis em https://digitalis.uc.pt/pt-pt/termos.

Conforme exposto nos referidos Termos e Condições de Uso, o descarregamento de títulos de acesso restrito requer uma licença válida de autorização devendo o utilizador aceder ao(s) documento(s) a partir de um endereço de IP da instituição detentora da supramencionada licença.

Ao utilizador é apenas permitido o descarregamento para uso pessoal, pelo que o emprego do(s) título(s) descarregado(s) para outro fim, designadamente comercial, carece de autorização do respetivo autor ou editor da obra.

Na medida em que todas as obras da UC Digitalis se encontram protegidas pelo Código do Direito de Autor e Direitos Conexos e demais legislação aplicável, toda a cópia, parcial ou total, deste documento, nos casos em que é legalmente admitida, deverá conter ou fazer-se acompanhar por este aviso.

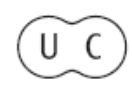




\section{RevCEDöUA}

N. ${ }^{0} 25$ _ Ano XIII_ 1.10

> Doutrina

Breve apontamento sobre a natureza jurídico-lributária da 'taxa'

sobre as lâmpadas de baixa eficiência energética

José Eduardo F. Dias

Joana Duarte Costa

A criaç̦ão de AMPs nas zonas da plataforma conlinental situadas além das 200 mn: Direito do Mar, CPLP e experiência portuguesa pós- 'hainbow'

Marta Chantal Ribeiro

A responsabilidade civil do estado brasileiro perante os riscos para o meio-ambiente do sequestro geológico de carbono

Lucas de Lima Carvalho

Da admissibilidade de meios extrajudiciais de resolução de confititos em matéria ambiental e urbanística - experiências presentes, possibilidades futuras

Cátia Marques Cebola

Concurso de Ideias e Estudos sobre a Revisão da Lei de Bases do Ambiente

Ana Cristina Vieira

> Jurisprudência

A desconsideração do nexo causal na responsabilidade civil ambiental

Neylene Fonseca

Recensões

Faclor Five: Transforming the Global Economu through 80\%

Improvements in Resource Productivity

Mariana Nicolau

Dossier

Ecossistemas de profundidade, AMPs oceânicas, plataforma continental além das 200mn e pioneirismo português

Marta Chantal Ribeiro

Ricardo Serrão Santos

Abstracts > Últimas Aquisições Bibliográficas

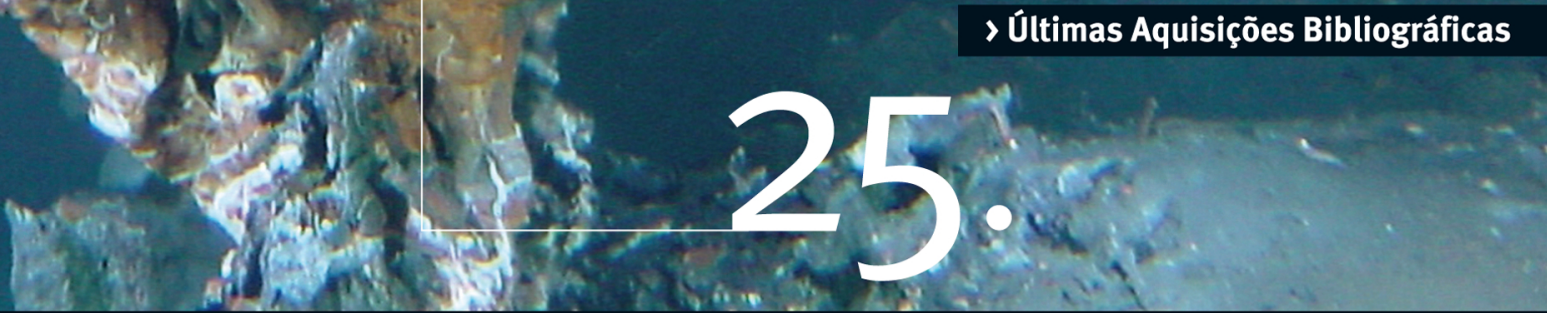

Revista do Centro de Estudos de Direito do Ordenamento, do Urbanismo e do Ambiente Urbanism, Territorial Order and Environment Studies Center Law Review 


\title{
A desconsideração do nexo causal na responsabilidade civil ambiental
}

\author{
RECURSO ESPECIAL № 1.090.968 - SP (2008/0207311-0) \\ RELATOR : MINISTRO LUIZ FUX \\ RECORRENTE : OSWALDO RIBEIRO DE MENDONÇA ADMINISTRAÇÃO E PARTICIPAÇÕES LTDA \\ ADVOGADO : MARISSOL MARIA DIAS DA SILVA E OUTRO(S) \\ RECORRIDO : MINISTÉRIO PÚBLICO DO ESTADO DE SÃO PAULO
}

\section{Relatório}

O EXMO. SR. MINISTRO LUIZ FUX (Relator): Trata-se de recurso especial interposto por OSWALDO RIBEIRO DE MENDONÇA, ADMINISTRAÇÃO E PARTICIPAÇÕES LTDA (fls. 356/390), com fulcro no art. 105, inciso III, alíneas "a" e "c", da Constituição Federal, contra acórdão prolatado pelo Tribunal de Justiça do Estado de São Paulo, assim ementado:

AÇÃO CIVIL PÚBLICA. Miguelópolis. LFno 4.771/65, art. 2ํo e 16. Recomposição em propriedade rural de cobertura florestal e averbação no Cartório Imobiliário da área de reserva legal. - 1. Reserva legal. Recomposição florestal. 0 art. 16 do Código Florestal, seguindo legislação mais antiga, reservou $20 \%$ das áreas privadas para preservação da cobertura florestal. A obrigação de recompor a cobertura decorre da $L F n^{\circ}-7.803 / 89$ de 18-7-1989 que, ao acrescentar 0 $\S 2-$ ao art. 16 do Código Florestal, desvinculou a reserva legal da pré-existência de matas ao estabelecê-la em no mínimo $20 \%$ 'de cada propriedade' e ao determinar sua averbação no cartório imobiliário e criou condições para a recomposição florestal ao nela vedar o corte raso (que implica na não exploração e na recomposição da vegetação); e da LF no 8.171/91 que, ao cuidar da política agrícola, determinou no art. 99 a recomposição das matas na reserva legal. Obrigação que decorre, ainda, do dever genérico de reparar o dano ambiental (CF, art.

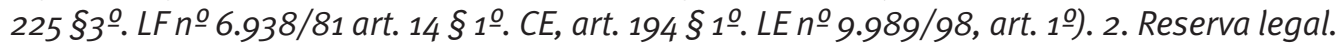
Averbação. A obrigação de averbar a reserva legal na matrícula do imóvel foi instituída pela LF $n^{\circ} 7.803 / 89$. Seu cumprimento não implica em aplicação retroativa às propriedades adquiridas antes dela ou em que as matas já haviam sido derrubadas, mas simples aplicação imediata da lei nova. Jurisprudência pacificada. - Sentença de procedência. Recurso desprovido. (fls. 323)

Opostos embargos de declaração, restaram rejeitados, consoante acórdão assim ementado:

EMBARGOS DE DECLARAÇÃO. Omissão e contradição. 1. Omissão. Configura-se a omissão quando o acórdão não aprecia questão que devia apreciar. Não há omissão quando o acórdão examina as questões e fundamentos necessários à solução controvérsia, deixando de lado questões irrelevantes, implicitamente rejeitadas ou que, pela natureza, não permitem apreciação nesse momento do processo. 2. Contradição. Os embargos de declaração permitem aclarar a contradição existente entre os termos do acórdão ('error in procedendo'), não sendo via própria para exame de possível contradição entre os termos do acórdão e outros elementos do processo ou fora dele. Contradição inexistente. - 3. Delimitação da reserva legal. $0 \S 4^{\circ}$ do art. 16 do Código Florestal especifica que o órgão 
ambiental aprovará a localização da área de reserva legal, evidentemente sob proposta do proprietário. Não diz que o proprietário fica dispensado de qualquer providência até que o órgão ambiental delimite a área de reserva legal de cada propriedade do país. 0 dispositivo legal foi mencionado no acórdão e sua redação fala por si mesma. Não há omissão. 4. Reserva legal. Desmatamento anterior. 0 acórdão, baseado em manifestações unívocas do STJ, afirma que a recomposição da reserva legal, obrigação imposta por lei, não implica em aplicação retroativa pela fato de a propriedade ter sido antes desmatada. Não há contradição. 0 inconformismo, de inadmissível natureza infringente, deve ser veiculado pela via própria. Embargos rejeitados. (fls. 350)

Versam os autos, originariamente, Ação Civil Pública ajuizada pelo MINISTÉRIO PÚBLICO DO ESTADO DE SÃO PAULO em face de OSWALDO RIBEIRO DE MENDONÇA, ADMINISTRAÇÃO E PARTICIPAÇÕES LTDA. Segundo consta, a requerida adquiriu propriedade degradada por ação de antigo proprietário. Sustentou que a preservação do meio ambiente é dever constitucionalmente imposto a todos, devendo a propriedade cumprir sua função social e a devida proteção daquele. Assim, a obrigação da restauração da área deveria ser observada pela adquirente e, tratando-se de obrigação propter rem, haveria de ser condenado pela degradação ao meio ambiente, com abstenção de explorar a área e penas de multa.

O Juiz da Primeira Vara da Comarca de Miguelópolis julgou parcialmente procedente 0 pedido, para condenar a requerida às seguintes obrigações: a) cumprimento de obrigação de não fazer, consistente em abster-se de explorar a reserva ecológica ou nela promover ou permitir que se promovam atividades danosas, ainda que parcialmente; b) recompor a cobertura florestal das áreas de preservação permanente, promovendo o plantio de 3.600 espécies de mudas nativas da região, no local da infração, mediante apresentação de projeto de recomposição florestal do empreendimento; c) demarcar e isolar a área de reserva ecológica em 50 metros de largura a partir da margem do reservatório, por toda sua extensão territorial; d) implantar aceiro com 10 metros de largura, a partir do término da área de preservação permanente, limpando-o anualmente; e) realização de atividades necessárias à manutenção e plantio, obrigando-se a repor as perdas, quando ultrapassarem $5 \%$ do plantio; f) proceder à averbação da reserva florestal legal, segundo as normas administrativas do DEPRN e à assinatura de termo de compromisso de preservação da reserva legal, assinalado prazo de 60 dias para cumprimento desse último item. Em caso de descumprimento, incidirá multa diária de $\mathrm{R} \$ 1.300,00$; consoante sentença exarada à fls. 254/262 dos autos.

Irresignada, a requerida interpôs apelação perante o Tribunal de Justiça do Estado de São Paulo, que negou provimento ao recurso, nos moldes delineados na ementa acima transcrita.

O Recorrente, em sede de recurso especial, sustenta, preliminarmente, ofensa ao art. 535, do Código de Processo Civil, notadamente porque, a despeito da oposição de embargos de declaração, o Tribunal local não examinou questões imprescindíveis ao deslinde da controvérsia posta nos autos.

No mérito, aduz:

a) ofensa ao art. 11 e 22, alínea "b", 23 e 71, todos do Decreto 23.793/34 e art. 60 da L.I. C.C., ao fundamento de que: i) durante o regime do Decreto 23.793/34 até o advento da Lei 4.771/65, a derrubada das áreas de florestas ainda existentes era expressamente permitida, exceto na hipótese da alínea 'b' do artigo 22; ii) em tal período não houve a obrigatoriedade de recomposição e/ou averbação da reserva legal; e que portanto, iii) o proprietário rural 
que tenha cometido tal feito na vigência de tal Decreto, nada deve à sociedade ou a Poder Público; realizou uma análise sistêmica daquele. (fls. 365). Sustenta que o Tribunal local analisou a questão com base no Código Florestal e legislação posterior, porém a análise deste Decreto se fazia necessária, porque com base em seu art. 11 a propriedade particular, ainda que coberta por florestas deveria estar previamente classificada como "protetora", através de Decreto do Governo Federal, e, ainda assim fossem apuradas as infrações na forma dos arts. 70 a 90 da referida legislação. Aduz que a úncia hipótese que previa regra geral aplicável a todos os imóveis rurais, independente da classificação ou não de suas florestas como protetora, era a prevista no art. 23 , em que nenhum proprietário de terras cobertas poderia abater mais de três quartas partes da vegetação existente, acarretando pena de detenção de até 60 dias e multa de dez contos de réus. Com isso conclui que na vigência do Decreto no 23.793/34, nada deve à sociedade e ao Poder Público, pela derrubada total ou parcial das florestas então existentes em seu imóvel, porque as chamadas áreas de preservação permanente ou de reserva legal somente passaram a existir com o advento do Código Florestal - Lei $n-4.771 / 65$, não podendo a lei nova retroagir para penalizar o atual proprietário;

b) negativa de vigência e contrariedade dos arts. 1ํㅡ, da MP no 2.166-67 de 25-8-200, 16 e 44, ambos da Lei no 4.771/65; 6 da L.I.C.C. e art. 5, inc. XXXVI, da Constituição Federal: ao fundamento de que pela leitura do Novo Código Florestal, com a nova redação dada pela MP $n^{0}$ 2.166-67, que o menciona $\S 2^{\circ}$ do artigo 16 , introduzida pela LF $n^{0} 7.803 / 89$,

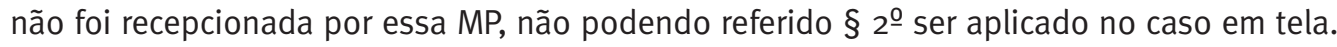
Por outro lado, afirma que mesmo que seja considerada eficaz a aplicabilidade da referida norma, esta somente se dá a partir de sua vigência e, considerando que a obrigatoriedade da averbação legal à margem da inscrição da matrícula do imóvel no registro de imóveis somente passou a vigorar com a Lei no $7.803 / 89$, é lícito dizer-se que este dispositivo somente atingiu as propriedades que continham, no mínimo, $20 \%$ de suas respectivas áreas cobertas por florestas nativas ou regeneradas. Desta forma, no caso, além de haver 71,57 ha de área com vegetação nativa, o que representa $11,72 \%$ de sua área total, não há por parte do proprietário exploração de florestas, tampouco limitação por parte do Poder Público das áreas de reserva legal, não incidindo a regra da averbação legal em cartório.

Conclui que a averbação da reserva legal só é condição obrigatória para aquele que desejar desmatar floresta ou outra forma de vegetação nativa;

c) divergência jurisprudencial citando como paradigmas o Recurso Especial no 229.302/ PR, DJ 07.02.2000, da Relatoria do Ministro Garcia Vieira e o Recurso Especial no 58.937, DJ 06.10.1997, da Relatoria do Ministro Ari Pargendler, sustentando que não cabe restauração de área nativa, quando a propriedade já foi adquirida regenerada; bem como que a averbação no Registro de Imóveis somente passou a ser exigível após a publicação da Lei nํㅜ 7.803/89.

O MINISTÉRIO PÚBLICO DO ESTADO DE SÃO PAULO, em contrarrazões (fls. 393/402), pugna, preliminarmente, pelo não conhecimento do recurso, e, caso superada a admissibilidade, pelo desprovimento da pretensão recursal.

O Recurso Especial resultou inadmitido no Tribunal a quo (fls. 428/429), subindo a esta Corte por força do provimento do AG 1009292/SP (fls.588).

O Ministério Público Federal, em parecer apresentado às 593/601, opina, pelo conhecimento parcial do recurso especial e, nesta parte, pelo não provimento, consoante ementa abaixo transcrita: 
RECURSO ESPECIAL. AÇÃO CIVIL PÚBLICA. DIREITO AMBIENTAL. RESERVA LEGAL. AVERBAÇÃO AUSÊNCIA DE PREQUESTIONAMENTO. SÚMULA 211/STJ. AUSÊNCIA DE OMISSÃO NOS EMBARGOS DE DECLARAÇÃO. I. Diante da inovação de fundamentos em sede de embargos de declaração, entende-se que não houve o necessário prequestionamento das matérias ali suscitadas, incidindo na espécie a Súmula 211 do STJ. II. Não há que se falar em violação ao artigo 535 do CPC quando os fundamentos utilizados no acórdão recorrido são suficientes para resolver a lide. III. Em se tratando de reserva florestal, com limitação imposta por lei, o novo proprietário, ao adquirir a área, assume o ônus de manter a preservação, tornando-se responsável pela reposição, mesmo que não tenha contribuído para devastá-la. IV. A averbação da reserva legal configura-se, portanto, como dever do proprietário ou adquirente de imóvel rural, nos termos do art. $8^{\circ}$, da Lei Federal no 4.771/1965, sem embargo da existência de florestas ou outras formas de vegetação nativa na gleba. V. Parecer pelo conhecimento parcial do recurso especial e, nesta parte, pelo não provimento do mesmo. (fls. 593)

É o relatório.

\section{RECURSO ESPECIAL № 1.090.968 - SP (2008/0207311-0)}

\section{Ementa}

PROCESSUAL CIVIL. ADMINISTRATIVO. DANOS AMBIENTAIS. AÇÃO CIVIL PÚBLICA. RESPONSABILIDADE DO ADQUIRENTE. TERRAS RURAIS. RECOMPOSIÇÃO. MATAS. TEMPUS REGIT ACTUM. AVERBAÇÃO PERCENTUAL DE 20\%. SÚMULA 07 STJ.

1. A responsabilidade pelo dano ambiental é objetiva, ante a ratio essendi da Lei $6.938 / 81$, que em seu art. 14 , $\S 1$, , determina que o poluidor seja obrigado a indenizar ou reparar os danos ao meio-ambiente e, quanto ao terceiro, preceitua que a obrigação persiste, mesmo sem culpa. Precedentes do STJ:RESP 826976/PR, Relator Ministro Castro Meira, DJ de 01.09.2006; AgRg no REsp 504626/PR, Relator Ministro Francisco Falcão, DJ de 17.05.2004; RESP 263383/PR, Relator Ministro João Otávio de Noronha, DJ de 22.08.2005 e EDcl no AgRg no RESP 255170/SP, desta relatoria, DJ de 22.04.2003.

2. A obrigação de reparação dos danos ambientais é propter rem, por isso que a Lei 8.171/91 vigora para todos os proprietários rurais, ainda que não sejam eles os responsáveis por eventuais desmatamentos anteriores, máxime porque a referida norma referendou o próprio Código Florestal (Lei 4.771/65) que estabelecia uma limitação administrativa às propriedades rurais, obrigando os seus proprietários a instituírem áreas de reservas legais, de no mínimo $20 \%$ de cada propriedade, em prol do interesse coletivo. Precedente do STJ: RESP 343.741/PR, Relator Ministro Franciulli Netto, DJ de 07.10.2002.

3. Consoante bem pontuado pelo Ministro Herman Benjamin, no REsp no $650728 / S C$, $2^{2}$ Turma, unânime: “(...) 11. É incompatível com o Direito brasileiro a chamada desafetação ou desclassificação jurídica tácita em razão do fato consumado. 12. As obrigações ambientais derivadas do depósito ilegal de lixo ou resíduos no solo são de natureza propter rem, o que significa dizer que aderem ao título e se transferem ao futuro proprietário, prescindindo-se de debate sobre a boa ou má-fé do adquirente, pois não se está no âmbito da responsabilidade subjetiva, baseada em culpa. 13. Para o fim de apuração do nexo de causalidade no dano ambiental, equiparam-se quem faz, quem não faz quando deveria fazer, quem deixa fazer, quem não se importa que façam, quem financia para que façam, e quem se beneficia quando outros fazem. 14 . Constatado o nexo causal entre a ação e a omissão das recorrentes com o dano ambiental em questão, surge, objetivamente, o dever de promover a recuperação da área afetada e indenizar eventuais danos remanescentes, na forma do art. 14, $\S 1^{\circ}$, da Lei 6.938/81.(...)". DJ 02/12/2009. 


\section{RerCED尚UA

4. Paulo Affonso Leme Machado, em sua obra Direito Ambiental Brasileiro, ressalta que

"(...)A responsabilidade objetiva ambiental significa que quem danificar o ambiente tem o dever jurídico de repará-lo. Presente, pois, o binômio dano/reparação. Não se pergunta a razão da degradação para que haja o dever de indenizar e/ou reparar. A responsabilidade sem culpa tem incidência na indenização ou na reparação dos "danos causados ao meio ambiente e aos terceiros afetados por sua atividade" (art. 14, § III, da Lei 6.938/81). Não interessa que tipo de obra ou atividade seja exercida pelo que degrada, pois não há necessidade de que ela apresente risco ou seja perigosa. Procura-se quem foi atingido e, se for o meio ambiente e o homem, inicia-se o processo lógico-jurídico da imputação civil objetiva ambienta!. Só depois que se entrará na fase do estabelecimento do nexo de causalidade entre a ação ou omissão e o dano. É contra o Direito enriquecer-se ou ter lucro à custa da degradação do meio ambiente.

O art. 927, parágrafo único, do CC de 2002, dispõe: "Haverá obrigarão de reparar o dano, independentemente de culpa, nos casos especificados em lei, ou quando a atividade normalmente desenvolvida pelo autor do dano implicar, por sua natureza, risco para os direitos de outrem". Quanto à primeira parte, em matéria ambiental, já temos a Lei 6.938/81, que instituiu a responsabilidade sem culpa. Quanto à segunda parte, quando nos defrontarmos com atividades de risco, cujo regime de responsabilidade não tenha sido especificado em lei, o juiz analisará, caso a caso, ou o Poder Público fará a classificação dessas atividades. "É a responsabilidade pelo risco da atividade."Na conceituação do risco aplicam-se os princípios da precaução, da prevenção e da reparação.

Repara-se por força do Direito Positivo e, também, por um princípio de Direito Natural, pois não é justo prejudicar nem os outros e nem a si mesmo. Facilita-se a obtenção da prova da responsabilidade, sem se exigir a intenção, a imprudência e a negligência para serem protegidos bens de alto interesse de todos e cuja lesão ou destruição terá conseqüências não só para a geração presente, como para a geração futura. Nenhum dos poderes da República, ninguém, está autorizado, moral e constitucionalmente, a concordar ou a praticar uma transação que acarrete a perda de chance de vida e de saúde das gerações(...)" in Direito Ambiental Brasileiro, Malheiros Editores, ${ }^{2}{ }^{a}$ ed., 2004, p. 326-327.

5. A Constituição Federal consagra em seu art. 186 que a função social da propriedade rural é cumprida quando atende, seguindo critérios e graus de exigência estabelecidos em lei, a requisitos certos, entre os quais o de "utilização adequada dos recursos naturais disponiveis e preservação do meio ambiente"

6. A adoção do princípio tempus regit actum, impõe obediência à lei em vigor quando da ocorrência do fato.

7. In casu, os fatos apurados como infração ambiental ocorreram no ano de 1997, momento em que já se encontrava em vigor o Código Florestal Lei no 4.771/65, não havendo que se perquirir quanto à aplicação do Decreto no 23.793/94, que inclusive foi revogado por aquela lei.

8. O Recurso Especial não é servil ao exame de questões que demandam o revolvimento do contexto fático-probatório dos autos, em face do óbice contido na Súmula 07/STJ.

9. In casu, a verificação da comprovação de que a propriedade não atinge o mínimo de $20 \%$ de área coberta por reserva legal, bem como a exploração de florestas por parte do proprietário, implicaria o revolvimento de matéria fática-probatória, o que é interditado a esta Corte Superior.

10. Deveras, o Tribunal a quo à luz de ampla cognição acerca de aspectos fático-probatórios concluiu que: A escusa dos requeridos de que não se pode impor a obrigação de reparar dano ambiental a particular que adquiriu a terra já desmatada ou que a averbação não pode ultrapassar o remanescente de mata nativa existente na área não convence; como bem exposto pelo Procurador de Justiça a fls. 313/314: 'não se pretende que a averbação seja feita anteriormente à entrada em vigor da Lei 7.803/89 que alterou disposições da Lei $4.771 / 65$. Ocorre que, a partir da vigência daquela primeira lei em nosso ordenamento jurídico, os antigos proprietários (Sr. Renato Junqueira de Andrade e Sra. Yolanda Junqueira de Andrade - fls. 77) tinham desde então a obrigação de ter averbado a reserva legal, sendo que 
a Ré, ao comprar uma propriedade sem observar os preceitos da lei, assumiu a obrigação dos proprietários anteriores ficando ressalvada, todavia, eventual ação regressiva. (fls. 335)

11. Os embargos de declaração que enfrentam explicitamente a questão embargada não ensejam recurso especial pela violação do artigo 535, II, do CPC, tanto mais que, o magistrado não está obrigado a rebater, um a um, os argumentos trazidos pela parte, desde que os fundamentos utilizados tenham sido suficientes para embasar a decisão.

12. Recurso parcialmente conhecido e, nesta parte, desprovido.

\section{Voto}

O EXMO. SR. MINISTRO LUIZ FUX (Relator): Preliminarmente, conheço do recurso especial pelas alíneas "a" e "c", do permissivo constitucional, uma vez que a matéria restou devidamente prequestionada, bem como demonstrada a divergência nos moldes estabelecidos pelo RISTJ.

Prima facie, conheço do recurso especial no que pertine à violação ao art. 535, do Código de Processo Civil, uma vez que referido dispositivo restou devidamente prequestionado.

Porém, não restou configurada a violação do art. 535 do CPC, uma vez que o Tribunal de origem, embora sucintamente, pronunciou-se de forma clara e suficiente sobre a questão posta nos autos. Saliente-se, ademais, que o magistrado não está obrigado a rebater, um a um, os argumentos trazidos pela parte, desde que os fundamentos utilizados tenham sido suficientes para embasar a decisão, como de fato ocorreu na hipótese dos autos. Neste sentido, os seguintes precedentes da Corte:

“AÇÃO DE DEPÓSITO. BENS FUNGÍVEIS. ARMAZÉM GERAL. GUARDA E CONSERVAÇÃO. ADMISSIBILIDADE DA AÇÃO. PRISÃO CIVIL. CABIMENTO. ORIENTAÇÃO DA TURMA. NEGATIVA DE PRESTAÇÃO JURISDICIONAL. INOCORRÊNCIA. RECURSO ESPECIAL. ENUNCIADO N. 7 DA SÚMULA/STJ. HONORÁRIOS ADVOCATÍCIOS. PROCESSO EXTINTO SEM JULGAMENTO DE MÉRITO. APLICAÇÃO DO \& $4^{\circ}$ DO ART. 2O, CPC. EQÜIDADE. RECURSO DO BANCO PROVIDO. RECURSO DO RÉU DESACOLHIDO.

(...)

III - Não padece de fundamentação o acórdão que examina suficientemente todos os pontos suscitados pela parte interessada em seu recurso. E não viola o art. 535-II o aresto que rejeita os embargos de declaração quando a matéria tida como omissa já foi objeto de exame no acórdão embargado.(...)" (REsp 396.699/RS, Rel. Min. Sálvio de Figueiredo Teixeira, DJ 15/04/2002)

"PROCESSUAL CIVIL. DECISÃO UNA DE RELATOR. ART. 557, DO CÓDIGO DE PROCESSO CIVIL. INTELIGÊNCIA A SUA APLICAÇÃO. INEXISTÊNCIA DE OMISSÃO NO ACÓRDÃO RECORRIDO. MATÉRIA DE CUNHO CONSTITUCIONAL EXAMINADA NO TRIBUNAL “A QUO”.

(...)

3. Fundamentos, nos quais se suporta a decisão impugnada, apresentam-se claros e nítidos. Não dão lugar, portanto, a obscuridades, dúvidas ou contradições. $O$ não acatamento das argumentações contidas no recurso não implica em cerceamento de defesa, posto que ao julgador cabe apreciar a questão de acordo com o que ele entender atinente à lide.

4. Não está obrigado o Juiz a julgar a questão posta a seu exame conforme o pleiteado pelas partes, mas, sim com o seu livre convencimento, utilizando-se dos fatos, provas, jurisprudência, aspectos pertinentes ao tema e da legislação que entender aplicável ao caso. (...) 
9. Agravo regimental não provido." (AGA 420.383, Rel. Min. José Delgado, DJ 29/04/2002)

Versam os autos, originariamente, Ação Civil Pública ajuizada pelo MINISTÉRIO PÚBLICO DO ESTADO DE SÃO PAULO em face de OSWALDO RIBEIRO DE MENDONÇA, ADMINISTRAÇÃO E PARTICIPAÇÕES LTDA, a obrigação da restauração de área adquirida pelo requerido com degradação ao meio ambiente, bem como a averbação de $20 \%$ da superfície da propriedade concernente à "reserva ambiental", reflorestamento e multa.

A responsabilidade pelo dano ambiental é objetiva, ante a ratio essendi da Lei 6.938/81, que em seu art. 14, § 1ํㅡ, determina que o poluidor seja obrigado a indenizar ou reparar os danos ao meio-ambiente e, quanto ao terceiro, preceitua que a obrigação persiste, mesmo sem culpa.

Sob esse enfoque confiram-se os seguintes julgados desta Corte:

“PROCESSUAL E ADMINISTRATIVO. ART. 535 DO CPC. ARGÜIÇÃO GENÉRICA. SÚMULA 284/ STF. ART. 18 DA LEI N.ํ 4.771/65. PREQUESTIONAMENTO. AUSÊNCIA. SÚMULAS 211/STJ E 282/STF. DISSÍDIO JURISPRUDENCIAL. FALTA DE COMPROVAÇÃO. DANO AO MEIO AMBIENTE. DEVER DE CONSERVAÇÃO INOBSERVADO. CONCLUSÃO DIVERSA. NECESSIDADE DE REEXAME DE PROVA. IMPOSSIBILIDADE. SÚMULA 7/STJ NOVO ADQUIRENTE DO IMÓVEL. LEGITIMAÇÃO PASSIVA. ORIENTAÇÃO PACIFICADA. SÚMULA 83/STJ.

(...)

2. Não decidida pela Corte de origem a questão federal referente ao art. 18 da Lei $n . \stackrel{o}{-}$ 4.771/65, inadmissível é o manejo do apelo especial, pois imperiosa a observância ao requisito do prequestionamento. São aplicáveis as Súmulas 211/STJ e 282/STF.

3. A mera transcrição da ementa do paradigma, sem a realização do necessário cotejo analítico, não é suficiente para comprovação da divergência, o que obsta o conhecimento do recurso pela alínea " $c$ ".

4. Fundado no acervo probatório dos autos, o Tribunal a quo asseverou que o recorrente seria responsável por perpetuar a lesão ao meio ambiente perpetrada pelo anterior proprietário do imóvel. Para concluir, como pretende a parte, que "não há nenhum elemento nos autos que comprove que o recorrente foi o responsável pelo desmatamento da área ou sequer a eventual existência desta", seria imprescindível revolver o suporte fático-probatório do feito, providência essa vedada pelo enunciado da Súmula $7 / S T$ J.

5. Ao adquirir a área, o novo proprietário assume o ônus de manter a preservação, tornando-se responsável pela reposição, mesmo que não tenha contribuído para o desmatamento. Precedentes de ambas as Turmas de Direito Público. Incidência da Súmula 83/STJ.

6. Recurso especial não conhecido." RESP 826976/PR, Relator Ministro Castro Meira, DJ de 01.09.2006)

ADMINISTRATIVO. AÇÃO CIVIL PÚBLICA. RESPONSABILIDADE. ADQUIRENTE. TERRAS RURAIS. DANOS AO MEIO-AMBIENTE. OBRIGAÇÃO. CONSERVAÇÃO DA ÁREA.

I - A questão enfrentada pelo recorrente encontra-se pacificada neste Superior Tribunal de Justiça, com o mesmo entendimento do acórdão recorrido, no sentido de que o particular que adquire propriedade rural tem responsabilidade pelo seu reflorestamento, mesmo quando já a adquira devastada, ante a transferência da obrigação de conservação da área.

II - Agravo regimental improvido." (AgRg no REsp 504626/PR, Relator Ministro Francisco Falcão, DJ de 17.05.2004)

ADMINISTRATIVO E PROCESSUAL CIVIL. RESERVA FLORESTAL. NOVO PROPRIETÁRIO. RESPONSABILIDADE OBJETIVA.

1. A responsabilidade por eventual dano ambiental ocorrido em reserva florestal legal é objetiva, devendo o proprietário das terras onde se situa tal faixa territorial, ao tempo em que conclamado para cumprir obrigação de reparação ambiental e restauração da cobertura vegetal, responder por ela. 
2. A reserva legal que compõe parte de terras de domínio privado constitui verdadeira restrição do direito de propriedade. Assim, a aquisição da propriedade rural sem a delimitação da reserva legal não exime o novo adquirente da obrigação de recompor tal reserva.

3. Recurso especial conhecido e improvido." (RESP 263383/PR, Relator Ministro João Otávio de Noronha, DJ de 22.08.2005)

EMBARGOS DE DECLARAÇÃO CONTRA ACÓRDÃO PROFERIDO EM AGRAVO REGIMENTAL. DANOS AMBIENTAIS. AÇÃO CIVIL PÚBLICA. RESPONSABILIDADE. ADQUIRENTE. TERRAS RURAIS. RECOMPOSIÇÃO. MATAS.

1. A Medida Provisória 1.736-33 de 11/02/99, que revogou o art. 99 da lei 8.171/99, foi revogada pela MP 2.080-58, de 17/12/2000.

2. Em matéria de dano ambiental a responsabilidade é objetiva. $O$ adquirente das terras rurais é responsável pela recomposição das matas nativas.

3. A Constituição Federal consagra em seu art. 186 que a função social da propriedade rural é cumprida quando atende, seguindo critérios e graus de exigência estabelecidos em lei, a requisitos certos, entre os quais o de "utilização adequada dos recursos naturais disponíveis e preservação do meio ambiente"

4. A lei 8.171/91 vigora para todos os proprietários rurais, ainda que não sejam eles os responsáveis por eventuais desmatamentos anteriores. Na verdade, a referida norma referendou o próprio Código Florestal (lei 4.771/65) que estabelecia uma limitação administrativa às propriedades rurais, obrigando os seus proprietários a instituírem áreas de reservas legais, de no mínimo $20 \%$ de cada propriedade, em prol do interesse coletivo.

5. Embargos de Declaração parcialmente acolhidos para negar provimento ao Recurso Especial." (EDcl no AgRg no RESP 255170/SP, desta relatoria, DJ de 22.04.2003)

A obrigação de reparação dos danos ambientais é propter rem, por isso que a Lei 8.171/91 vigora para todos os proprietários rurais, ainda que não sejam eles os responsáveis por eventuais desmatamentos anteriores, máxime porque a referida norma referendou o próprio Código Florestal (art. 16, $\S 2^{0}$ da 4.771/65) que estabelecia uma limitação administrativa às propriedades rurais, obrigando os seus proprietários a instituírem áreas de reservas legais, de no mínimo $20 \%$ de cada propriedade, em prol do interesse coletivo.

Sobre o thema destaque-se, pela juridicidade de suas razões, os fundamentos desenvolvidos pelo Ministro Franciulli Netto no julgamento de hipótese análoga:

“(...)Com efeito, desde o início do século passado, o Estado Brasileiro vem se preocupando em editar normas que promovam o eqüilíbrio ambiental, razão pela qual a proteção das florestas já estava positivada desde 1934, com o Decreto $n$. 23.793, de 23 de janeiro desse ano.

O artigo 2- do "Novo Código Florestal", Lei n. 4.771, de 15 de setembro de 1965, dispõe que:

"Art. $2^{\circ}$ Consideram-se de preservação permanente, pelo só efeito desta Lei, as florestas e demais formas de vegetação natural situadas:

a) ao longo dos rios ou de outro qualquer curso d'água, em faixa marginal cuja largura mínima será:

1 - de 5 (cinco) metros para os rios de menos de 10 (dez) metros de largura".

Com o advento da Lei n. 6.938, de 31 de agosto de1981, as áreas de preservação permanente foram transformadas em reservas ou estações ecológicas, consoante se pode observar pela leitura do seu artigo 18, a seguir transcrito:

"Art 18 - São transformadas em reservas ou estações ecológicas, sob a responsabilidade da SEMA, as florestas e as demais formas de vegetação natural de preservação permanente, relacionadas no art. $2^{\circ}$ da Lei no 4.771, de 15 de setembro de 1965 - Código Florestal, e os 
pousos das aves de arribação protegidas por convênios, acordos ou tratados assinados pelo Brasil com outras nações".

O referido diploma, ainda, inaugurou a responsabilização objetiva dos causadores de danos ambientais, nos termos do $\S 1^{\circ}$, do seu artigo 14, a seguir transcrito:

"Art. 14 - Sem prejuízo das penalidades definidas pela legislação federal, estadual e municipal, o não cumprimento das medidas necessárias à preservação ou correção dos inconvenientes e danos causados pela degradação da qualidade ambiental sujeitará os transgressores:

(...)

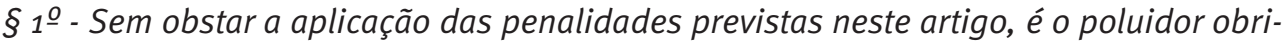
gado, independentemente da existência de culpa, a indenizar ou reparar os danos causados ao meio ambiente e a terceiros, afetados por sua atividade (...)".

o Código Florestal estabelece, por seu turno, em seu artigo 16, que deve ser excluída da exploração econômica a chamada reserva legal, constituída por $20 \%$ de todas "as florestas de domínio privado".

Ora, como está explícito na legislação acima mencionada, tanto a faixa ciliar quanto a reserva legal, em qualquer propriedade, incluída a da recorrente, não podem ser objeto de exploração econômica, de maneira que, ainda que se não dê o reflorestamento imediato, referidas zonas não podem servir como pastagens.

Não há cogitar, pois, de ausência de nexo causal, visto que aquele que perpetua a lesão ao meio ambiente cometida por outrem está, ele mesmo, praticando o ilícito.

Ainda que assim não fosse, se a manutenção da área destinada à preservação permanente é obrigação propter rem, ou seja, decorre da relação existente entre o devedor e a coisa, a obrigação de conservação é automaticamente transferida do alienante ao adquirente, independentemente deste último ter responsabilidade pelo dano ambiental.

Eventual prejuízo deverá ser discutido, por meio de ação própria, entre o adquirente e o alienante que efetivamente provocou o dano.

É oportuno ressaltar que não buscou a ação civil pública, que culminou com a interposição do presente recurso especial, impor à recorrente a obrigação de reflorestamento, mas sim, a abstenção de utilização da "área da 'faixa ciliar' e da 'reserva legal', não mais a explorando e deixando-a aos cuidados da Natureza (fl. o5 e o6), com base na legislação mencionada na petição inicial" (fl. 105).

Verifica-se, dessarte, que a divergência jurisprudencial não está configurada, uma vez que os acórdãos paradigmas colacionados pela recorrente cuidam da obrigação de reflorestamento das áreas desmatadas e não da exploração econômica das áreas de preservação permanente e da reserva legal, tema efetivamente discutido nos autos.(...)" (RESP 343.741) $P R$, Relator Ministro Franciulli Netto, DJ de 07.10.2002)

Consoante bem pontuado pelo Ministro Herman Benjamin, no REsp no 650728/SC, $2^{\underline{a}}$ Turma, unânime: “(...) 11. É incompatível com o Direito brasileiro a chamada desafetação ou desclassificação jurídica tácita em razão do fato consumado. 12. As obrigações ambientais derivadas do depósito ilegal de lixo ou resíduos no solo são de natureza propter rem, o que significa dizer que aderem ao título e se transferem ao futuro proprietário, prescindindo-se de debate sobre a boa ou má-fé do adquirente, pois não se está no âmbito da responsabilidade subjetiva, baseada em culpa. 13. Para o fim de apuração do nexo de causalidade no dano ambiental, equiparam-se quem faz, quem não faz quando deveria fazer, quem deixa fazer, quem não se importa que façam, quem financia para que façam, e quem se beneficia quando outros fazem. 14. Constatado o nexo causal entre a ação e a omissão das recorrentes com o dano ambiental em questão, surge, objetivamente, o dever de promover a recuperação da área afetada e indenizar eventuais danos remanescentes, na forma do art. 14, § $1^{\circ}$, da Lei 6.938/81.(...)". DJ 02/12/2009. 


\section{$\operatorname{RerCED\varrho ̈UA~}$}

> Jurisprudência

Paulo Affonso Leme Machado, em sua obra Direito Ambiental Brasileiro, ressalta que:

“(...) A Lei da Política Nacional do Meio Ambiente consagra como um de seus objetivos a "imposição ao poluidor e ao predador da obrigação de recuperar e/ou indenizar os danos causados" (art..4으, VII, da Lei 6.938, de 31.8.91). Além disso, possibilita o reconhecimento da responsabilidade do poluidor em indenizar e/ou reparar os danos causados ao meio ambiente e aos terceiros afetados por sua atividade, independentemente da existência de culpa (art. 14, $\S P \backslash$ da lei referida). A aplicação da penalidade administrativa, prevista nos ines. I, II, fi e IV do art. 14 não elide a indenização ou reparação que o Poder Judiciário possa cominar, como se vê sem qualquer dúvida no § 12 do aludido art. 14.

A Lei de Responsabilidade por Dano Nuclear (art. 42, caput, da Lei 6.453, de 17.10.1977) e a Convenção Internacional sobre Responsabilidade Civil em Danos Causados por Poluição por Óleo, de 1969, promulgada pelo Decreto 79.347, de 28.3.1977, prevêem a responsabilidade objetiva ou sem culpa.

José de Aguiar Dias, em sua magnífica obra Da Responsabilidade Civil, ressalta que a "situação desejável é do equilíbrio, onde impere a conciliação entre os direitos do homem e seus deveres para com os seus semelhantes. O conflito de interesses não é permanente, como quer fazer crer a doutrina extremista, mas ocasional. E quando ele ocorre, então, sem nenhuma dúvida, o que há de prevalecer é o interesse da coletividade". Não se pode aceitar, continua o jurista, "que o direito de um pode prejudicar a outro, pode ultrapassar as raias da normalidade e fazer do seu titular um pequeno monarca absoluto". 10

Não se aprecia subjetivamente a conduta do poluidor, mas a ocorrência do resultado prejudicial ao homem e seu ambiente. "A responsabilidade jurídica atualmente orienta-se para os seus objetivos que são aqueles do Direito, a saber, a utilidade social e a justiça em relação às partes em litígio" - assinala Genevieve Viney.ll

A atividade poluente acaba sendo uma apropriação pelo poluidor dos direitos de outrem, pois na realidade a emissão poluente representa um confisco do direito de alguém em respirar ar puro, beber água saudável e viver com tranqüilidade. Por isso, é imperioso que se analisem oportunamente as modalidades de reparação do dano ecológico, pois muitas vezes não basta indenizar, mas fazer cessar a causa do mal, pois um carrinho de dinheiro não substitui o sono recuperador, a saúde dos brônquios, ou a boa formação do feto.

A responsabilidade objetiva ambiental significa que quem danificar o ambiente tem o dever jurídico de repará-lo. Presente, pois, o binômio dano/reparação. Não se pergunta a razão da degradação para que haja o dever de indenizar e/ou reparar. A responsabilidade sem culpa tem incidência na indenização ou na reparação dos "danos causados ao meio ambiente e aos terceiros afetados por sua atividade" (art. 14, § III, da Lei 6.938/81). Não interessa que tipo de obra ou atividade seja exercida pelo que degrada, pois não há necessidade de que ela apresente risco ou seja perigosa. Procura-se quem foi atingido e, se for o meio ambiente e o homem, inicia-se o processo lógico-jurídico da imputação civil objetiva ambienta!. Só depois é que se entrará na fase do estabelecimento do nexo de causalidade entre a ação ou omissão e o dano. É contra o Direito enriquecer-se ou ter lucro à custa da degradação do meio ambiente.

0 art. 927, parágrafo único, do CC de 2002, dispõe: "Haverá obrigarão de reparar o dano, independentemente de culpa, nos casos especificados em lei, ou quando a atividade normalmente desenvolvida pelo autor do dano implicar, por sua natureza, risco para os direitos de outrem". Quanto à primeira parte, em matéria ambiental, já temos a Lei 6.938/81, que instituiu a responsabilidade sem culpa. Quanto à segunda parte, quando nos defrontarmos com atividades de risco, cujo regime de responsabilidade não tenha sido especificado em lei, o juiz analisará, caso a caso, ou o Poder Público fará a classificação dessas atividades. "É a responsabilidade pelo risco da atividade." Na conceituação do risco aplicam-se os princípios da precaução, da prevenção e da reparação. 
Repara-se por força do Direito Positivo e, também, por um princípio de Direito Natural, pois não é justo prejudicar nem os outros e nem a si mesmo. Facilita-se a obtenção da prova da responsabilidade, sem se exigir a intenção, a imprudência e a negligência para serem protegidos bens de alto interesse de todos e cuja lesão ou destruição terá conseqüências não só para a geração presente, como para a geração futura. Nenhum dos poderes da República, ninguém, está autorizado, moral e constitucionalmente, a concordar ou a praticar uma transação que acarrete a perda de chance de vida e de saúde das gerações(...)" in Direito Ambiental Brasileiro, Malheiros Editores, ${ }^{2}{ }^{\stackrel{a}{ }}$ ed., 2004, p. 326-327.

Por derradeiro, cumpre-nos acrescentar, a Constituição Federal consagra em seu art. 186 que a função social da propriedade rural é cumprida quando atende, seguindo critérios e graus de exigência estabelecidos em lei, a requisitos certos, entre os quais o de "utilização adequada dos recursos naturais disponíveis e preservação do meio ambiente".

Ultrapassada a questão atinente à responsabilidade pela reparação dos danos ambientais, subjaz o exame da aplicação do Decreto no $23.793 / 34$ ou a Lei 4.771/65.

A adoção do princípio tempus regit actum, impõe obediência à lei em vigor quando da ocorrência do fato. In casu, os fatos apurados como infração ambiental ocorreram no ano de 1997, momento em que já se encontrava em vigor o Código Florestal Lei no 4.771/65, não havendo que se perquirir quanto à aplicação do Decreto $n-23.793 / 94$, que inclusive foi revogado por aquela lei.

De outro lado, o Recurso Especial não é servil ao exame de questões que demandam o revolvimento do contexto fático-probatório dos autos, em face do óbice contido na Súmula o7/ST).

In casu, a verificação da comprovação de que a propriedade não atinge o mínimo de $20 \%$ de área coberta por reserva legal, bem como a exploração de florestas por parte do proprietário, implicaria o revolvimento de matéria fática-probatória, o que é interditado a esta Corte Superior.

Deveras, o Tribunal a quo à luz de ampla cognição acerca de aspectos fático-probatórios concluiu que: A escusa dos requeridos de que não se pode impor a obrigação de reparar dano ambiental a particular que adquiriu a terra já desmatada ou que a averbação não pode ultrapassar o remanescente de mata nativa existente na área não convence; como bem exposto pelo Procurador de Justiça a fls. 313/314: 'não se pretende que a averbação seja feita anteriormente à entrada em vigor da Lei 7.803/89 que alterou disposições da Lei 4.771/65. Ocorre que, a partir da vigência daquela primeira lei em nosso ordenamento jurídico, os antigos proprietários (Sr. Renato Junqueira de Andrade e Sra. Yolanda Junqueira de Andrade - fls. 77) tinham desde então a obrigação de ter averbado a reserva legal, sendo que a Ré, ao comprar uma propriedade sem observar os preceitos da lei, assumiu a obrigação dos proprietários anteriores ficando ressalvada, todavia, eventual ação regressiva. (fls. 335)

Expositis, conheço parcialmente do recurso especial e, nesta parte, nego-lhe provimento.

É como voto. 


\section{Acórdão}

Vistos, relatados e discutidos estes autos, os Ministros da PRIMEIRA TURMA do Superior Tribunal de Justiça acordam, na conformidade dos votos e das notas taquigráficas a seguir, Prosseguindo o julgamento, após o voto-vista do Sr. Ministro Teori Albino Zavascki, a Turma, por unanimidade, conhecer parcialmente do recurso especial e, nessa parte, negar-lhe provimento, nos termos do voto do Sr. Ministro Relator. Os Srs. Ministros Teori Albino Zavascki (voto-vista), Benedito Gonçalves e Hamilton Carvalhido votaram com o Sr. Ministro Relator.

Manifestou-se pelo MINISTÉRIO PÚBLICO FEDERAL, o Exmo. Sr. Dr. AURÉLIO VIRGílIO VEIGA RIOS, Subprocurador-Geral da República.

Brasília (DF), 15 de junho de 2010 (Data do Julgamento)

MINISTRO LUIZ FUX

Relator

\section{Comentário}

\section{Enquadramento}

Muito antes das normas ambientais protetivas existirem no Brasil, como o Código Florestal, Lei $n=0$ 4.771 de 1965 , os proprietários rurais já desmatavam suas terras para aproveitar a madeira e outros recursos resultantes do processo de desmatamento e transformá-las em áreas de maior utilização econômica, como lavouras ou pasto.

Por conseguinte, sítios que, atualmente, a Lei determina que tenham cobertura vegetal, foram desmatados e nunca recompostos, até que a fiscalização dos órgãos públicos de defesa ambiental passou a exigir a reparação e, ainda, a aplicar multas (sanções administrativas) ao proprietário, pelo suposto dano ambiental.

No processo em comento, a questão posta foi a aquisição de uma propriedade rural que já não possuía área original de mata dentro do limite mínimo estabelecido pela Lei, de $20 \%$ do total. Foi alegado pela parte requerida, que tal desmatamento ocorreu em época anterior à Lei e que não havia sido praticado pelo atual proprietário, razão pela qual não deveria, este, responder pelo dano ambiental e sim aquele que o causara.

Em resposta, o Ministério Público, autor da ação civil pública que originou o acórdão analisado, alegou que o dever de recompor a mata e registrá-la como reserva legal é daquele que a adquiriu na vigência da Lei, mesmo que não tenha sido o responsável pela sua derrubada. 
A decisão do Tribunal de Justiça de origem, nomeadamente do Estado de São Paulo, foi confirmada pelo acórdão em tela, proferido pelo Superior Tribunal de Justiça ${ }^{1}$ (ST)), no sentido de desconsiderar o nexo causal entre aquele que desflorestou a área e a obrigação de reflorestar, considerando esse dever como vinculado ao título de propriedade, logo, daquele que o detém.

Este é o contexto para diversas ações julgadas pelo STJ, que, desde o ano 2000, tem proferido acórdãos, como o que está sendo analisado, em matéria de responsabilidade civil ambiental, buscando relacionar o dano àquele que estiver na condição mais rápida de repará-lo, mesmo que para isso seja desconsiderado o princípio do poluidor pagador e atribuída a responsabilidade a terceiro.

O impasse gerado por essa nova linha de argumentação, é que, ao desconsiderar o nexo para atribuição de responsabilidade, é preciso determinar outro parâmetro para identificar o responsável pelas obrigações ambientais. No caso verificado, de ausência de reserva legal, tem sido atribuída nova natureza jurídica à obrigação de recomposição, como sendo obligatio propter rem, ou seja, uma obrigação que adere e segue à propriedade, atribuindo ao titular do direito de propriedade os deveres do poluidor.

Cria-se, entretanto, um possível conflito entre essa nova corrente e os preceitos da responsabilidade civil ambiental, bem como com o princípio do poluidor pagador. Principalmente, porque o acórdão se baseia nesses conceitos e não na previsão expressa do artigo 44ํ do Código Florestal, incluído por meio de Medida Provisória ํㅜ 2.166-67 de 24 de agosto de 2001, de que o dever de recompor a mata para fins de reserva legal, segue a propriedade e vincula seu titular ou seu possuidor.

Assim, a análise passará pelos pontos relativos à responsabilidade civil ambiental e pela verificação da legalidade do dever atribuído ao atual proprietário de reconstituir a mata para fins de reserva legal.

\section{A responsabilidade civil ambiental}

0 ponto número 1 da ementa do acórdão diz: "A responsabilidade pelo dano ambiental é objetiva, ante a ratio essendi da Lei 6.938/81, que em seu art. 14, $\S 1^{0}$, determina que o poluidor seja obrigado a indenizar ou reparar os danos ao meio-ambiente e, quanto ao terceiro, preceitua que a obrigação persiste, mesmo sem culpa".

A responsabilidade ambiental brasileira possui vertentes civis, administrativas e penais, sendo possível a tripla responsabilização por um mesmo ato, conforme determinação constitucional expressa: "as condutas e atividades consideradas lesivas ao meio ambiente sujeitarão os infratores, pessoas físicas ou jurídicas, a sanções penais e administrativas, independentemente da obrigação de reparar os danos causados"².

\footnotetext{
${ }^{1}$ O Superior Tribunal de Justiça brasileiro tem sua competência firmada no artigo 105 da Constituição da República Federativa do Brasil, e é a última instância de julgamento de causas com matéria infraconstitucional, bem como é a corte responsável por uniformizar a interpretação da legislação federal. In: STJ. Atribuições. Disponível em «http:// www.stj.gov.br/portal_stj/publicacao/engine.wsp?tmp.area=293» acesso em 08 dez. 2010.

${ }^{2}$ BRASIL. Constituição da República Federativa do Brasil. Brasília: Senado Federal, 1988. Art. 225, § 3º.
} 


\section{$\operatorname{RerCED\varrho ̈UA~}$}

> Jurisprudência

Neste mesmo sentido, o artigo $14^{\circ}$, $\S 1^{\circ}$, da Lei n. 6.938/81- Lei da Política Nacional do Meio Ambiente - estabeleceu o regime da responsabilidade civil objetiva, dispondo: “sem obstar à aplicação das penalidades previstas neste artigo, é o poluidor obrigado, independentemente de existência de culpa, a indenizar ou reparar os danos causados ao meio ambiente e a terceiros, efetuados por sua atividade".

Por ser a responsabilidade civil ambiental brasileira objetiva, admite-se que seja desconsiderada a análise da culpa ou do dolo, mantendo-se apenas a verificação do dano e do nexo causal. José Alfredo de Oliveira Baracho Junior ${ }^{3}$ conceitua essa forma de responsabilidade como "os danos e a reparação não devem ser definidos pela medida da culpabilidade, mas devem surgir do fato causador da lesão a um bem jurídico”.

Além da exclusão da culpabilidade, também desconsideram-se quaisquer outros fatores, como caso fortuito e força maior, conforme parte da doutrina brasileira defende, nas palavras de Solange Teles da Silva4:

“O dever de reparar independe da análise da subjetividade do agente e aquele que cria o risco deve reparar os danos advindos do seu empreendimento. Não há probabilidade de alegar qualquer excludente de responsabilidade, quer dizer, não importa nem a legalidade do ato, nem a força maior, ou o caso fortuito".

Nesse diapasão, salienta-se que a responsabilidade ambiental, exprime mais que uma função indenizatória e reparatória quando se depara com o dano ambiental ou ecológico, pois ela possui uma natureza educativa, que visa inibir a reincidência da prática do ato lesivo a partir de uma conscientização por meio da sanção.

\subsection{O Dano Ambiental}

O dano é a agressão que exige a aplicação da responsabilidade. Sérgio Cavalieri Filho5, conceitua dano para a responsabilidade civil como "prejuízo a terceiro, que enseja pedido de reparação consistente na recomposição do status quo ante ou uma importância em dinheiro - indenização".

Paulo Affonso Leme Machado ${ }^{6}$ citando Helita Barreira Custódio, diz que:

“Para fins de reparação, o dano decorrente da atividade poluente tem como pressuposto básico a própria gravidade do acidente, ocasionando prejuízo patrimonial ou não patrimonial a outrem, independente de se tratar de risco permanente, periódico, ocasional ou relativo".

Para o direito brasileiro ocorre dano ambiental quando há lesão a um bem jurídico de natureza ambiental, não sendo discutido se esse bem tem importância direta ou indireta para o Homem.

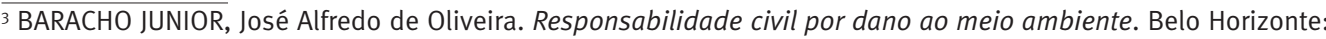
Del Rey, 1999, p. 297.

${ }^{4}$ SILVA, Solange Teles da. Responsabilidade civil ambiental. In: PHILIPPI, Arlindo; ALVES, Alaôr Caffé (Eds). Curso Interdisciplinar de direito ambiental. Barueri/SP: Manole, 2005, p. 445.

${ }^{5}$ FILHO, Sérgio Cavalieri. Programa de Responsabilidade Civil. 5 ed. São Paulo: Malheiros, 2003, p.88-89.

${ }^{6}$ MACHADO, Paulo Affonso Leme.Responsabilidade Civil por danos ao meio ambiente. tese de livre-docência, USP, 1983, p. 307. 
Para o direito português a definição de dano passa por uma análise mais detalhada, conforme se vê a partir da leitura do preâmbulo do Decreto-Lei no $147 / 2008$, que trata da Responsabilidade Ambiental:

“Durante muitos anos a problemática da responsabilidade ambiental foi considerada na perspectiva do dano causado às pessoas e às coisas. 0 problema central consistia na reparação dos danos subsequentes às perturbações ambientais - ou seja, dos danos sofridos por determinada pessoa nos seus bens jurídicos da personalidade ou nos seus bens patrimoniais como consequência da contaminação do ambiente. Com o tempo, todavia, a progressiva consolidação do Estado de direito ambiental determinou a autonomização de um novo conceito de danos causados à natureza em si, ao património natural e aos fundamentos naturais da vida. [...] Assim, existe um dano ecológico quando um bem jurídico ecológico é perturbado, ou quando um determinado estado-dever de um componente do ambiente é alterado negativamente". (grifo nosso)

Considerando essa distinção entre dano ambiental e dano ecológio do direito português e aplicando ao caso da eliminação de vegetação nativa, o dano pode ser considerado como ambiental, pois atinge diretamente o equilíbrio natural do qual depende a vida humana, visto que a retirada de grandes áreas de mata tem consequências graves, como a desertificação, a desregulação do clima, dos gases atmostéricos e das chuvas, a extinção de espécies, entre tantas outras.

Entretanto, é necessário verificar se a não recomposição da vegetação nativa configura dano ambiental, isto é, se é possível haver dano causado por omissão do particular, visto que, tal conceito foi alargado pelo acórdão, que entende que a não recuperação de áreas de mata também se classifica como dano ambiental, uma vez adotando a posição do Ministro Herman Benjamin?:

“Para o fim de apuração do nexo de causalidade no dano ambiental, equiparam-se quem faz, quem não faz quando deveria fazer, quem deixa fazer, quem não se importa que façam, quem financia para que façam, e quem se beneficia quando outros fazem. (...) Constatado o nexo causal entre a ação e a omissão das recorrentes com o dano ambiental em questão, surge, objetivamente, o dever de promover a recuperação da área afetada e indenizar eventuais danos remanescentes, na forma do art. $14^{\circ}$, $§ 1^{\circ}$, da Lei 6.938/81 (...)”.

Ora, dentro do conceito de poluidor, é a atividade ou a ação deste, que resulta em ofensa a um bem ambiental e que pode ser classificada como dano ambiental. Para que a omissão também pudesse ser considerada tal qual a ação, primeiro deveria haver a previsão expressa em Lei, e não uma equiparação doutrinária, como consta no acórdão, e segundo, deveria resultar em dano, assim como a ação.

Neste caso, o bem ambiental que poderia ser alvo da lesão (a mata), já não existe mais, e a obrigação que se busca é a de fazer, ou seja, de criar. O que é contrário às obrigações de não fazer, de não desmatar, por não ser mais possível de fazê-lo, visto que o desmatamento já ocorreu em época anterior à Lei.

\footnotetext{
${ }_{7}$ Posição do Ministro Herman Benjamim no REsp nํ6 650728/SC, 2 2 Turma, unânime, que foi usado como fundamento pelo relator Ministro Luiz Fux, no acórdão analisado relativo ao REsp nํㅜ 1.090.968/SP.
} 


\section{$\operatorname{RerCEDळ̈UA~}$ \\ > Jurisprudência}

\subsection{0 nexo causal}

O nexo de causalidade pode ser entendido a partir da sua leitura mais simples, como uma relação de causa e efeito entre o autor e o dano, e é a ligação entre o responsável pela ação e seus efeitos. Sérgio Cavalieri Filho ${ }^{8}$, ao tratar da responsabilidade objetiva, deixa claro o foco que deve ser dado ao nexo causal, quando diz que "todo prejuízo deve ser atribuído ao seu autor e reparado por quem o causou, independentemente de ter ou não agido com culpa”.

No direito civil, a obrigatoriedade da presença do nexo de causalidade não é questionada, pois a necessidade de verificar essa relação é incontestável para que se possa determinar os sujeitos ativos e passivos e os obrigar a cumprir seus deveres. Considerando que a responsabilidade ambiental tem sua esfera civil e que é sobre essa que versam os deveres indenizatórios e compensatórios, não pode, por apenas ter como objeto lesionado um bem ambiental, fugir às regras básicas da responsabilidade civil comum, tendo por necessidade a verificação de dano e nexo causal, quando objetiva.

O princípio no. 16 da Declaração ECO - 92 sobre Ambiente e Desenvolvimento, deixa claro que a obrigação do poluidor é a de suportar os custos de sua poluição. 0 que demonstra a necessidade de verificação do nexo de causalidade para se atribuir deveres.

"Princípio no 16. As autoridades nacionais devem procurar promover a internalização dos custos ambientais e o uso de instrumentos econômicos, tendo em vista a abordagem segundo a qual o poluidor deve, em princípio, arcar com o custo da poluição, com a devida atenção ao interesse público e sem provocar distorções no comércio e nos investimentos internacionais" 9 .

Entretanto, parte da doutrina ambiental brasileira, que foi usada para fundamentar o acórdão em comento, estabelece um conceito de nexo mais amplo do que aquele pré-existente entre a ação e o dano, estabelecendo nexo em casos de omissão, ou seja, diante do dever de fazer, cria o vínculo de causalidade pelo não fazer. Retomando o problema sobre a possibilidade do particular que, ao descumprir a obrigação de recompor a mata, estaria gerando dano ambiental ou apenas infringindo a Lei.

Paulo de Bessa Antunes ${ }^{10}$ diz que "a manutenção da reserva legal é uma obrigação legal que deriva da própria coisa. É certo que, em circunstâncias especiais poderá haver simultaneamente a prática do dano ambiental. Esta, no entanto, somente se caracterizará em relação àquele que por ação ou omissão direta deu causa à destruição da RL ${ }^{11}$."

Assim, a omissão do proprietário só configuraria dano ambiental, quando representasse uma lesão ao bem ambiental, possibilidade não estabelecida a partir do descumprimento da Lei em recompor a reserva legal.

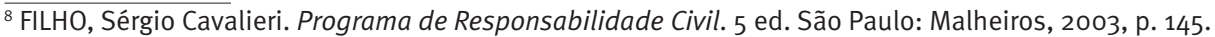

9 CONFERÊNCIA DAS NAÇÕES UNIDAS SOBRE AMBIENTE E DESENVOLVIMENTO. Declaração ECO-92 sobre Ambiente e Desenvolvimento. 1992. Rio de Janeiro.

${ }^{10}$ ANTUNES, Paulo de Bessa. Poder Judiciário e reserva legal: análise de recentes decisões do Superior Tribunal de Justiça, RDA, ano 6, n. 21, jan./março de 2001, p. 127.

${ }^{11}$ RL é a abreviação de reserva legal feita pelo autor Paulo de Bessa Antunes.
} 


\subsection{0 autor do dano e o princípio do poluidor pagador}

Para a responsabilidade civil ambiental, o autor do dano tem os deveres de reparação e de compensação, de forma que, na figura mais objetiva, o autor do dano é considerado como poluidor, formalizando o princípio do poluidor pagador na sua concepção mais clara.

Este é o sentido dado pela Lei no 6.938/81, de política ambiental brasileira, em seu artigo $3^{\circ}$, IV, que conceitua o poluidor como "a pessoa física ou jurídica, de direito público ou privado, responsável, direta ou indiretamente, por atividade causadora de degradação ambiental".

Para o direito brasileiro, o poluidor pagador não pode ser entendido como uma autorização de pagar para poluir, ou poluir e apenas pagar, pelo contrário, ele paga porque poluiu e não para ter o direito poluir, visto que, direito à poluição não existe. No poluidor recaem todos os custos de proteção, prevenção e reparação dos danos ambientais, bem como da utilização racional dos recursos ambientais.

A interpretação da Lei pode ser mais ampla, quando dá conotação econômica ao princípio do poluidor pagador e estabelece um limite ao enriquecimento do poluidor pela prática reiterada da sua atividade, havendo uma obrigação implícita de reter esses custos e não repassá-los à sociedade. Considerando ainda, que no Brasil não há obrigação legal de se fazer seguro ambiental e, são raros os casos em que essa contratação de seguro é feita por iniciativa própria do particular, na maioria das vezes, o titular da atividade econômica assume o risco e todos os custos do dano que sua ação possa causar ao ambiente.

Para parte da doutrina portuguesa, a definição do poluidor passa por uma análise que abrange também os demais sujeitos da cadeia produtiva e de consumo, tendo em conta o fenômeno da repercussão, que "consiste na transferência dos pagamentos efetuados pelo poluidor, para os seus clientes e opera-se pela inclusão dessas despesas, como um custo, no preço final dos bens ou serviços, onerando reflexamente o respectivo adquirente" ${ }^{12}$.

Havendo repercussão, o poluidor não arca verdadeiramente com todos os custos de sua poluição, já que o consumidor final também estará pagando, embutidos no preço final do produto, pelos impactos negativos ao ambiente causados pela atividade produtiva. Se tal efeito fosse aplicado ao caso do acórdão, o atual proprietário das áreas não preservadas, ao ser obrigado a perder parte de sua área economicamente utilizável para recompor com matas até o percentual exigido pela Lei, deveria repassar sua perda à sociedade no valor do produto.

Essa possibilidade existe quando se trata de grandes produtores que dominam o mercado, representando uma alta de preços, mas não pode ser considerada como regra para aqueles pequenos proprietários rurais, que vendem a produção a cooperativas ou diretamente ao consumidor, sendo um desestímulo à atividade rural.

Essa colocação é baseada no fato de haver propriedades de todos os tamanhos e com as mais diversas atividades no Brasil e que, indistintivamente, são atingidas por essa nova interpretação do STJ. Dessa forma, ao se tratar de pequenas produções agrícolas ou

\footnotetext{
${ }_{12}$ ARAGÃO, Maria Alexandra de Sousa. O Princípio do Poluidor Pagador: Pedra angular da política comunitária do ambiente. Coimbra: Coimbra Editora, 1997, p. 187.
} 


\section{$\operatorname{RerCED\varrho ̈UA~}$ \\ > Jurisprudência}

apenas de subsistência, o pequeno proprietário suporta sozinho os custos da recuperação ambiental, enquanto os grandes proprietários podem amortizar os custos, transferindo-os ao sujeito seguinte da cadeia produtiva.

Não parece que tal situação seja desejável, mesmo havendo dificuldades em aplicar, na prática, o dever de internalizar os custos ambientais e retirá-los do próprio lucro. Entende-se que, pelo princípio do poluidor pagador, o responsável pelo impacto ambiental negativo tem o dever de suportar esses custos causados pela sua atividade econômica.

\section{A reserva legal e a obrigação ambiental}

O ponto número 2 da ementa do acórdão, diz que: "A obrigação de reparação dos danos ambientais é propter rem, por isso que a Lei 8.171/91 vigora para todos os proprietários rurais, ainda que não sejam eles os responsáveis por eventuais desmatamentos anteriores, máxime porque a referida norma referendou o próprio Código Florestal (Lei 4.771/65) que estabelecia uma limitação administrativa às propriedades rurais, obrigando os seus proprietários a instituírem áreas de reservas legais, de no mínimo $20 \%$ de cada propriedade, em prol do interesse coletivo".

Neste contexto, a reserva legal faz parte da concepção geral de que os direitos de propriedade serão exercidos com as limitações legais, no que toca às florestas e demais formas de vegetação, quando reconhecidas de utilidade às terras que revestem e serão protegidas por serem bem de interesse comum a todos os habitantes do país ${ }^{13}$.

O Código Florestal brasileiro determina que, em cada propriedade rural, seja reservada área com preservação e manutenção de matas para a constituição de reserva legal, cujo conceito foi renovado no Código Florestal pela redação da Medida Provisória no‥ 2.166-67, de 24 de agosto de 2001, ao artigo $1^{\circ}$, § $2^{\circ}$, da Lei ํㅡ. 4.771 de 1965, que dispõe, no inciso III:

“Reserva Legal: área localizada no interior de uma propriedade ou posse rural, excetuada a de preservação permanente, necessária ao uso sustentável dos recursos naturais, à conservação e reabilitação dos processos ecológicos, à conservação da biodiversidade e ao abrigo e proteção de fauna e flora nativas".

De forma objetiva, a reserva legal é uma parte demarcada de cada propriedade, cujo tamanho é definido a partir da localização no território nacional, em que o proprietário tem a obrigação de deixar com cobertura vegetal típica do ecossistema regional, e deve seguir os seguintes parâmetros dados pela mesma Lei, em seu artigo 16을

“I - oitenta por cento, na propriedade rural situada em área de floresta localizada na Amazônia Legal;"

“Il - trinta e cinco por cento, na propriedade rural situada em área de cerrado localizada na Amazônia Legal, sendo no mínimo vinte por cento na propriedade e quinze por cento na forma de compensação em outra área, desde que esteja localizada na mesma microbacia, e seja averbada nos termos do $\S 70$ deste artigo;"

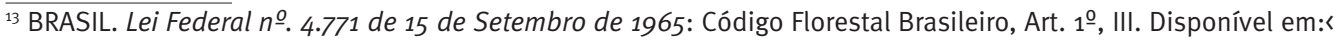
www.planalto.gov.bry. Acesso em: 18 nov. 2010. 
"III - vinte por cento, na propriedade rural situada em área de floresta ou outras formas de vegetação nativa localizada nas demais regiões do País; e”

“IV - vinte por cento, na propriedade rural em área de campos gerais localizada em qualquer região do País".

Até agora, a controvérsia esteve ligada ao dever de preservar essas áreas dentro dos percentuais estabelecidos pela Lei. Mas o acórdão ora em análise, versa sobre situação onde inexiste área vegetal a ser preservada que satisfaça o mínimo legal de $20 \%$. O STJ, então, afirma que a obrigação de recompor a reserva legal é inerente a quem adquire ou é titular do direito de propriedade, mas não se valeu do argumento legal trazido pelo Código

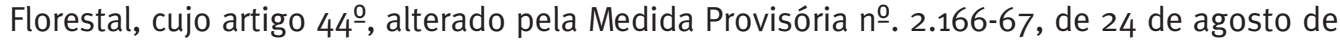
2001, equipara o proprietário ao possuidor de imóvel rural, e determina que estes, caso não possuam, em suas terras, a cobertura vegetal mínima para compor a reserva legal, devem adotar as seguintes medidas, alternativas, isoladas ou conjuntamente:

“I - recompor a reserva legal de sua propriedade mediante o plantio, a cada três anos, de no mínimo 1/10 da área total necessária à sua complementação, com espécies nativas, de acordo com critérios estabelecidos pelo órgão ambiental estadual competente;"

“Il - conduzir a regeneração natural da reserva legal; e"

“III - compensar a reserva legal por outra área equivalente em importância ecológica e extensão, desde que pertença ao mesmo ecossistema e esteja localizada na mesma microbacia, conforme critérios estabelecidos em regulamento".

No entanto, quando o STJ afirma genericamente que a obrigação de reparação dos danos ambientais é propter rem, foge ainda mais do sentido da lógica do Direito Ambiental, pois cria extensões que desequilibram a responsabilidade civil ambiental, trabalhando com o conceito de nexo causal pela via da omissão, e foge do principal fundamento que poderia haver adotado, que é o dever legalmente estabelecido de recompor, regenerar e compensar a reserva legal.

\section{Ponderações jurídicas e fáticas sobre o acórdão}

O ponto número 5 da ementa do acórdão assevera que, “A Constituição Federal consagra em seu art. 186 que a função social da propriedade rural é cumprida quando atende, seguindo critérios e graus de exigência estabelecidos em Lei, a requisitos certos, entre os quais o de 'utilização adequada dos recursos naturais disponíveis e preservação do meio ambiente”".

Demonstrando que a exigência da recomposição da mata também se fundamenta nos propósitos de função social da propriedade, que de acordo com a Constituição da República Federativa do Brasil (CRFB), especificamente no artigo no. 186, para que as propriedades rurais alcancem sua função socioambiental, é preciso haver o aproveitamento racional, a utilização adequada dos recursos naturais disponíveis e a preservação do meio ambiente.

Diante da atenção aos requisitos constitucionais, para que a propriedade rural cumpra sua função socioambiental, é preciso colaborar para o equilíbrio ecológico, o que é feito, entre outras coisas, por meio da criação e manutenção de uma área vegetal protegida, 
denominada reserva legal. 0 acórdão em análise trata de casos de propriedades rurais, em que a inexistência de cobertura vegetal mínima, nomeadamente reserva legal, é considerada como dano ambiental, logo, também, não cumpre a sua função socioambiental.

Ora, havendo dispositivo legal para basear a posição do STJ, entende-se que falhou o acórdão ao argumentar fundamentando-se na responsabilidade civil, e em uma desconsideração do nexo de causalidade entre o desmatamento e o proprietário atual, que adquiriu o imóvel já desprovido de cobertura arbórea. Assim, a decisão criou uma brecha jurídica desnecessária, pois, ao desconsiderar o nexo causal para as situações de reserva legal, abre a possibilidade para que a mesma desconsideração possa ocorrer em outros casos de dano ambiental, por exemplo, poluição relativa a recursos hídricos, à atmosfera, ao solo e ao subsolo, perda da biodiversidade e outros, sem que o Estado, dessa forma, se sinta no dever de encontrar o verdadeiro autor, responsabilizando aquele que julgar mais acessível.

Neste caso em específico, uma Medida Provisória, editada pelo Poder Executivo com força de Lei, mas que prescinde de todo o processo legislativo ordinário, proporcionou o fundamento para atribuir uma nova natureza jurídica à obrigação de recompor a reserva legal. Entretanto, o STJ, além de não abordar a solução legal, forçou uma flexibilização dos fundamentos da responsabilidade civil ambiental, ao tratar a inexistência de reserva como dano ambiental.

A preocupação se justifica, pois relacionar o dano ambiental com uma obrigação inerente à propriedade, ultrapassa o limite da Lei atinente à reserva legal e atinge situações diversas, como invasões de terceiros, incêndios criminosos ou furto de bens ambientais. Como saber em quais hipóteses o proprietário pode ou não ser penalizado, sem a verificação da sua relação com o fato danoso?

Destaca-se ainda, que, os reflexos dessa posição jurisprudencial não ficam restritos somente aos processos judiciais, pois decisões administrativas de órgãos do Poder Executivo são muitas vezes fundamentadas em precedentes jurisprudenciais dos tribunais superiores e tal matéria está em constante apreciação, o que poderá resultar em decisões administrativas com caráter meramente sancionatório, versando sobre os mais diversos fatos, entretanto, com fundamento na desconsideração do nexo de causalidade.

Ou seja, para que a jurisprudência em voga não causasse os problemas suscitados, deveria o STJ, segundo aqui se entende, trabalhar com a base legal e não com a responsabilidade civil a partir do dano ambiental e da desconsideração do nexo causal, pois a ausência de reserva legal não se enquadra no conceito clássico de dano ambiental, e nem é preciso inovar quanto a um nexo por a omissão.

Porém, na perspectiva dessa decisão, o atual proprietário terá que recompor a cobertura arbórea, não por ser poluidor ou por poder ser submetido aos deveres deste como se o fosse, mas sim porque é proprietário de um imóvel que apresenta esse ônus e que está em desacordo com a Lei, já que a reserva legal onera a propriedade e se transmite aos sucessores do seu título.

\subsection{As obrigações relativas à gestão de resíduos em Portugal}

No Direito português, há previsão legal de desconsideração do nexo de causalidade para atribuição de responsabilidade no caso de gestão de resíduos. De forma que, não 
é necessário comprovar o vínculo entre o produtor de resíduos com seu produto, para determinar aquele que responderá pelo resíduo.

Essa possibilidade está no Decreto-Lei no. 178/2006, de 5 de setembro, que aprovou o regime geral da gestão de resíduos, especificamente no artigo $5^{\circ}, n^{\circ}-1$, que trata da responsabilidade da gestão e estabelece que "a gestão do resíduo constitui parte integrante do seu ciclo de vida, sendo da responsabilidade do respectivo produtor".

Ou seja, inicialmente, a responsabilidade é mesmo do produtor, entretanto, para salvaguardar a realização da gestão, mesmo em casos que não seja identificado aquele que produziu o resíduo, o citado Decreto-Lei, estabelece novas possibilidades de atribuir responsabilidades, sendo elas previstas nos números 3 e 4 do mesmo artigo 5웅

“3 - Em caso de impossibilidade de determinação do produtor do resíduo, a responsabilidade pela respectiva gestão recai sobre o seu detentor”.

“4 - Quando os resíduos tenham proveniência externa, a sua gestão cabe ao responsável pela sua introdução em território nacional, salvo nos casos expressamente definidos na legislação referente à transferência de resíduos”.

Dessa forma, mesmo em situações nas quais o proprietário de uma área seja vítima da ação de terceiros não identificáveis, que depositem resíduos de forma irregular em sua propriedade, ainda assim terá que responder por esses resíduos e por sua correta gestão.

Essa situação é mantida pela Diretiva $\mathrm{n}$ 0 2008/98/CE, de 19 de novembro, do Parlamento Europeu e do Conselho, transposta em 12 de dezembro de 2010 para Portugal, e que traz em seu artigo 3aㅡ, no 6 a definição de detentor de resíduos como "o produtor dos resíduos ou a pessoa singular ou colectiva que tem os resíduos na sua posse". Equiparando-se o produtor àquele que possa ter os resíduos em sua posse.

No acórdão em comento, há rápida menção sobre a questão dos resíduos no Brasil, sendo considerado pelo ministro Herman Benjamin ${ }^{14}$, também sem citação de Lei, que a natureza jurídica das obrigações relativas ao lixo também é propter rem, desconsiderando o nexo causal entre produtor e seu produto. Nesse sentido, afirma o voto do Ministro: "As obrigações ambientais derivadas do depósito ilegal de lixo ou resíduos no solo são de natureza propter rem, o que significa dizer que aderem ao título e se transferem ao futuro proprietário, prescindindo-se de debate sobre a boa ou má-fé do adquirente, pois não se está no âmbito da responsabilidade subjetiva, baseada em culpa”.

\section{Conclusão}

O acórdão analisado tem enorme relevância, pois abre precedentes sobre a flexibilização da responsabilidade civil ambiental, fugindo da clássica composição ato, dano e nexo causal entre eles para determinar o responsável. Dessa forma, a decisão gera insegurança jurídica ao desconsiderar o nexo de causalidade entre ação e dano, o que é visto quando

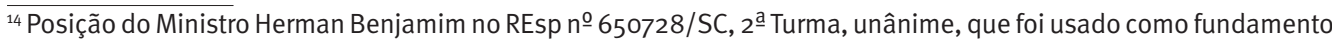
pelo relator Ministro Luiz Fux, no acórdão analisado relativo ao REsp no $1.090 .968 / \mathrm{SP}$.
} 


\section{$\operatorname{RerCED\varrho ̈UA~}$}

> Jurisprudência

o real causador do dano ambiental não assume o ônus de sua prática, pelo contrário, quem é obrigado a assumí-lo é aquele que adquiriu a propriedade já desmatada e nem mesmo contribuiu para a concretização do desmatamento.

A solução encontrada nesse acórdão pode ter seu mérito sob a ótica ambiental, mas, conforme aqui se entende, é arriscada e desnecessária diante da previsão do Código Florestal da obrigação relativa à reserva legal e do proprietário para com seu imóvel. Deveria, por conseguinte, ter seguido a determinação do artigo 44 do citado diploma legal, para fundamentar a obrigação como propter rem e determinar a recomposição ou compensação da área de reserva legal, ao invés de se basear em uma idéia equivocada de dano.

Cabe ressaltar que, a responsabilidade pelo inadimplemento legal, não é a mesma aplicada a casos em que o dano ambiental foi configurado, não podendo ser tratado o proprietário rural, que não possui a reserva legal, como um poluidor qualquer, quando nem sua ação, nem mesmo sua omissão, atingiram bem juridico ambientalmente protegido.

Nesse sentido, muito embora a decisão pareça estar imbuída das melhores intenções em prol do ambiente e de sua proteção, não será pela via da flexibilização da norma e muito menos da desconsideração do nexo de causalidade, que se terá o meio ambiente equilibrado, previsto na Constituição da República Federativa do Brasil como um direito de todos, mas sim pelo respeito a Lei.

Neylene Fonseca Souza

Advogada

Mestranda e Direito do Ordenamento, do Urbanismo e do Ambiente pela Faculdade de Direito da Universidade de Coimbra

\section{Referências}

ANTUNES, Paulo de Bessa. Poder Judiciário e reserva legal: análise de recentes decisões do Superior Tribunal de Justiça, RDA, ano 6, n. 21, jan./março de 2001.

ARAGÃO, Maria Alexandra de Sousa. O Princípio do Poluidor Pagador: Pedra angular da política comunitária do ambiente. Coimbra: Coimbra Editora, 1997.

BARACHO JUNIOR, José Alfredo de Oliveira. Responsabilidade civil por dano ao meio ambiente. Belo Horizonte: Del Rey, 1999.

BRASIL. Constituição da República Federativa do Brasil. Brasília: Senado Federal, 1988.

BRASIL. Lei Federal no 4.771 de 15 de Setembro de 1965: Código Florestal Brasileiro. Disponível em:く www. planalto.gov.bry. Acesso em: 18 nov. 2010.

BRASIL. Superior Tribunal de Justiça. Atribuições. Disponível em «http://www.stj.gov.br/portal_stj/publicacao/ engine.wsp?tmp.area=293» acesso em 08 dez. 2010.

CONFERÊNCIA DAS NAÇÕES UNIDAS SOBRE AMBIENTE E DESENVOLVIMENTO. Declaração ECO-92 sobre Ambiente e Desenvolvimento. 1992. Rio de Janeiro.

FILHO, Sérgio Cavalieri. Programa de Responsabilidade Civil. 5 ed. São Paulo: Malheiros, 2003.

MACHADO, Paulo Affonso Leme. Responsabilidade Civil por danos ao meio ambiente. tese de livre-docência, USP, 1983.

SILVA, Solange Teles da. Responsabilidade civil ambiental. In: PHILIPPI, Arlindo; ALVES, Alaôr Caffé (Eds). Curso Interdisciplinar de direito ambiental. Barueri/SP: Manole, 2005. 